\title{
Biology of Bone Graft and the Use of Bovine Bone for Revision of Total Hip Arthroplasty with Acetabular Reconstruction
}

\author{
Carlos Roberto Galia, Fernando Pagnussato, \\ Tiango Aguiar Ribeiro and Luis Fernando Moreira \\ Additional information is available at the end of the chapter \\ http://dx.doi.org/10.5772/intechopen.79485
}

\begin{abstract}
The use of bone graft in orthopaedic surgeries has become essential in many situations in which there is a bone defect. This includes bone tumour procedures, fracture operations where there was a loss of bone tissue and revision arthroplasty surgeries. In this chapter, we will introduce aspects related to history of bone transplantation, the biological and mechanical aspects, as well sterilization, transmission of infectious diseases and biological safety, and concluding, the functioning of tissue banks and screening of musculoskeletal tissue donors.
\end{abstract}

Keywords: bone graft, revision of total hip arthroplasty, acetabular reconstruction, biological and mechanical aspects of bone tissue, tissue banks

\section{Introduction}

The use of transplants in orthopaedic surgeries has become essential in many situations in which there is a bone defect. This includes bone tumour procedures, fracture operations where there was a loss of bone tissue and revision arthroplasty surgeries [11, 44, 53]. The latter, revision arthroplasty, has considerably increased since the rate of primary arthroplasties has grown substantially in recent years. Some kind of musculoskeletal tissue is transplanted into 10 to $15 \%$ of orthopaedic surgeries performed in the United States. Annually, about 650,000 bone-based grafts are distributed by the American Tissue Banks, clearly highlighting 
the importance of processing, controlling and storing of this type of material becoming one of the major transplanted tissues [44, 59].

Bone tissue can be processed in many ways. It can be stored longer and has been implanted till recently without prior testing compatibility as opposed to transplant of other organs and the vast majority of soft tissues. Nevertheless, the bone tissue can be obtained from patient's own body called autograft, from another donor of the same species (living or cadaver donors) called homograft, from donors of another species xenograft and from non-organic biomaterials [2]. Despite the success of these implants, patients who require transplant may wait quite a few years on transplant lists. These lists have grown considerably in recent years, either from public hospitals or from private ones [3].

Deep-frozen homologous graft is the most common used bone graft, but its use is limited due to shortage and although small, the risks of transmitting contagious diseases and even cancers should not be overlooked [11,44]. On the other hand, though homologous lyophilised (freeze-dried) grafts have virtually eliminated the risk of transmissible diseases is still lacking availability and therefore, alternative biomaterials from synthetic or natural source have been considered and carefully studied. Among these materials, the use of bovine lyophilised grafts is a suitable alternative with many advantages over autologous or homologous lyophilised graft ones due to the great physicochemical and structural resemblance to human bone and their practically endless availability $[13,15,16,45]$. As a xenograft however, it may possibly present adverse immunological and inflammatory reactions [16]. Nevertheless, our physicochemical processing protocols have been developed in order to significantly reduce these problems, decreasing antigenicity and thus, turning the bovine freeze-dried bone an important biomaterial for large scale use in reconstructive surgery [14, 63].

The bone tissue transplanting is far from being a novel issue, but it is necessary an increased knowledge about some kinds of grafts, their mechanical and biological aspects, sources and a careful analysis of outcomes. Bone transplant is responsible for an improvement in patient's quality of life; in some cases, return to daily life activities and promotion of patient social reinsertion. This chapter is intended to present a brief review of the history of bone grafts, indications for use, storage details and differences of processing techniques as well as to present the experience of our hip orthopaedic surgery group with the use of lyophilised bovine xenograft in almost two thousand orthopaedic procedures.

\section{History of bone transplantation}

In the first centuries of the Christian era, the idea of tissue transplantation between individuals of the same species and even of different species arose. Cosmas and Damian, considered the pioneers of bone transplantation, in the second century of Christian era removed a tumour-affected leg and soon implanted a leg taken from a recently killed Moro. But success in bone transplantation only came in 1880 with Sir William MacEwan who reconstructs a patient humerus with bone graft from another patient's leg. But Job van Meekren in 1668 was the first who realise a xenograft bone transplant. Meekren transplanted part of the skull of a 
dog in a traumatic defect of the skull of a soldier, who was excommunicated by the church. The soldier asked the surgeon to remove the graft, but due to time elapsed, this could not be completely removed since it was already fully integrated. Ollier and Barth in nineteenth century concluded, though not fully correct, that bone and periosteum remained viable when transplanted, contributing to new bone formation; arising the primary concept that cells survive in the graft even when removed from donor [3, 52]. In an important and considered a classical work, Albee concluded that the most suitable tissues for transplant are those originated from connective tissue such as bone, fat and fascia $[12,19,30]$.

\section{Biological aspects}

The bone tissue is composed of $10 \%$ water, an inorganic part (mineral, mainly hydroxyapatite) corresponding to $65 \%$, and an organic part corresponding to $25 \%$, being this latter part consisting of a collagen type I matrix with low molecular weight proteoglycans and noncollagen proteins [21].

When affected by severe bone loss or osteolysis, a condition founded in several cases of total hip arthroplasty revision, the bone tissue cannot be repaired, even though it is a tissue with high recovery power. In these cases, it is necessary to use bone grafts or bone substitutes (biomaterials) that fill this gap and restore patient's bone stock [21].

Bone grafts can be of three types, depending on the location of its origin: cortical, cancellous or cortical-cancellous. These grafts can be used in three modes: blocks, segments or morselised. These different types of bone grafts will provide distinct mechanical and biological responses. The cortical bone is less osteogenic than the spongy one, showing however, a higher structural quality, for long periods and even in the absence of adequate integration. In revision arthroplasty surgeries cancellous bone graft remains the choice due to its greater osteogenic features $[11,18,27,34,49,50,61]$.

A sequence of events begins after transplantation of a spongy bone, starting by an inflammatory response. This is followed by macrophage invasion, neovascularization and differentiation of mesenchymal cells into osteoblasts that place an osteoid layer on a remaining necrotic trabecular bone. Viable nuclei are reabsorbed by osteoblasts and the matrix is eventually replaced by necrotic trabeculae in the newly formed bone [57]. Urist and Hernandez in their classical study demonstrated ectopic bone formation after implantation of demineralised bovine bone matrix in rabbit's muscular tissue. This discovery showed that certain substances present in bone matrix induce cell differentiation. All these events are probably mediated by inducing protein factors, called bone morphogenetic proteins (BMPs) that have great osteogenic activity [39, 43]. These BMPs belong to a superfamily of proteins called transforming growth factors beta (TGFß) responsible for inducing growth. The TGF- $B$ is responsible for cell growth, differentiation and embryo formation. BMPs have been shown to be important regulators in the development and regeneration of skeletal tissue [43]. Buma and colaborators detailed Galia [14] in their PhD thesis, in 2000 and 2004 (Figures 1 and 2), respectively, demonstrated the relationship between time elapsed from grafting till to biopsies for histological analysis. The wider the interval, the larger 


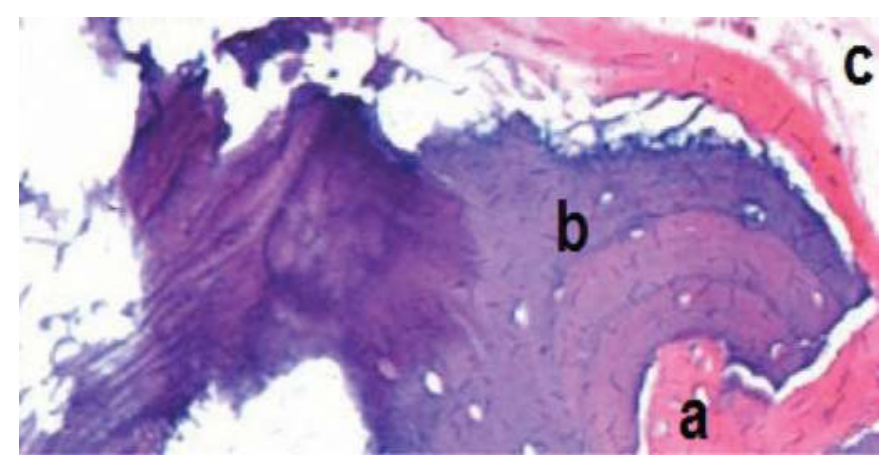

Figure 1. A representative case with a severe bone loss before a primary total hip arthroplasty was submitted to a revision total hip arthroplasty with acetabular bone reconstruction with bovine lyophilized xenograft. This patient was affected by recurrent dislocation of the revised arthroplasty. An inadequate positioning of the acetabular component was the aetiology. A biopsy of the acetabular bone graft reconstruction was done in the second revision surgery. In this case, the time elapsed from the first revision with the bone grafting and the second revision made to reposition the acetabulum was nine months. a: new bone formed; b: lyophilised bovine xenograft; c: fibrous tissue.

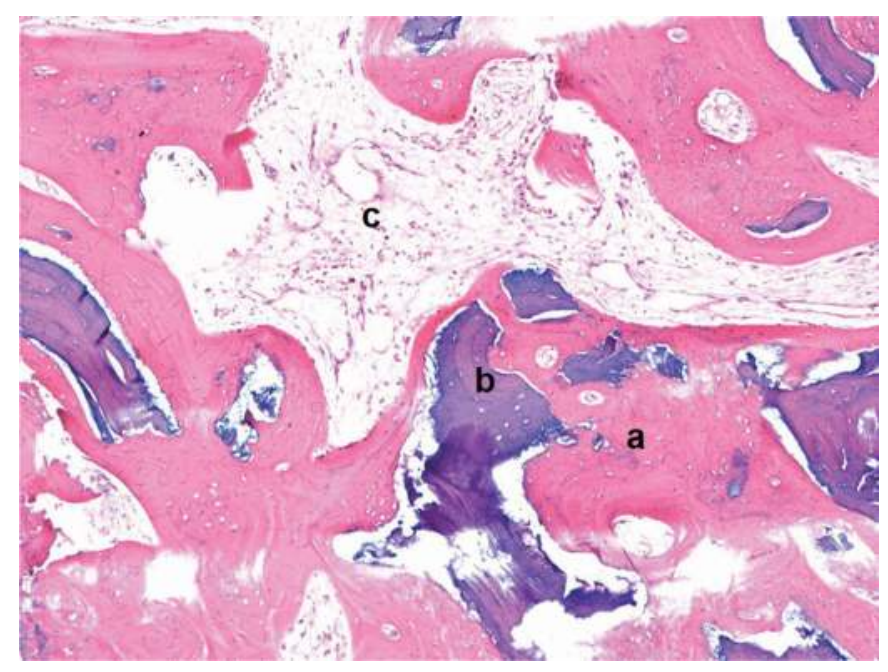

Figure 2. Another patient with a severe bone loss before a primary total hip arthroplasty was submitted to a revision total hip arthroplasty with acetabular bone reconstruction with bovine lyophilized xenograft. This patient was affected by recurrent dislocation of the revised arthroplasty. An inadequate positioning of the acetabular component was the aetiology. A biopsy of the acetabular bone graft reconstruction was done in the second revision surgery. In this case, the time elapsed from the first revision with the bone grafting and the second revision made to reposition the acetabulum was 43 months. a: new bone formed; b: lyophilised bovine xenograft; c: fibrous tissue.

the amount of new bone formation and the smaller the residual bone graft, though Tiango et al. in 2015 [44] in a case series resulted from his $\mathrm{PhD}$ thesis was notable to reconfirm these findings, probably due to the small number of cases with biopsies in the study $[5,17,18,58]$. 
Out come in bone transplantation also depends on antigenic reaction factors. Some grafts have proved to be extremely antigenic, depending on the antigens present in these grafts. The antigenic reactions are mediated by bone marrow cells and not by $\mathrm{T}$ or B lymphocytes. Indeed, in vitro studies demonstrated that lineages of bone marrow granulocytes appear to be responsible for this immune response [7]. Moreover, in vivo studies in rabbits also showed that fresh grafts, frozen grafts and lyophilised bovine xenograft express distinct immune responses. Fresh and frozen grafts led to systemic response in rabbits as opposed to lyophilised bovine xenograft where rabbits were not able to develop such systemic immune response, demonstrating that the lyophilisation process clears up immunologically the graft by removing all the fat and bone marrow cells [13].

\section{Mechanical aspects}

The different mechanical aspects of the various types of graft play a key role when a graft is to be chosen. These differences can lead to distinct end-results and therefore acquaintance with these mechanical aspects is of a paramount prominence.

Several physical properties of human and bovine trabecular bone have been reported [26, 54]. The compressive strength to mechanical forces varied between 2.44 and $6.24 \mathrm{MPa}$ in both, human and bovine bones. In Young's module analyses the results of both bones varied between 70 and $673 \mathrm{MPa}$ [42]. Galia et al [15]. in 2011 obtained a similar result between lyophilised bovine and lyophilised human bones for the scanning electron microscope analyses on the pore sizes of the trabecular bone. The mean pore size was $316 \mu \mathrm{m}$, ranging from 91.2 to $497.8 \mu \mathrm{m}$ to bovine lyophilised bone and $333.5 \mu \mathrm{m}$, ranging from 87.2 to $963.9 \mu \mathrm{m}$ to human lyophilised bone. Macedo et al [36]. in 1999 in an in vitro study demonstrated that frozen lyophilised bovine bone defrosted or rehydrated for an hour have similar compressive load and deformation rates. Cornu et al [6] in 2001 showed that lyophilized morcelised and impacted human bones were mechanically superior to morcelised and impacted deep-frozen ones. However, the resistance of both bones was similar after impaction [36].

\section{Sterilisation, transmission of infectious diseases and biological safety}

The sterilisation is a crucial issue involving grafts and it can change their mechanical properties, as well as may affect transmission of diseases or even tumours [60, 64]. Radiation as Cobalt 60 can significantly reduce bone mechanical properties and even in low doses can destroy morphogenetic properties, in a progressive dose-dependent manner over the bone biomechanics [10]. Several authors studied gamma radiation and other sterilisation methods (ethanol and ethylene oxide at $55^{\circ} \mathrm{C}$ ) and their effect on graft osteoinduction. Gamma radiation with $25 \mathrm{kGy}$ inactivate HIV virus but reduces osteoinduction capacity of grafts in nearly $40 \%$; ethylene oxide at $55^{\circ} \mathrm{C}$ provides an almost complete loss of this important potential. On the other hand, ethanol has not affected osteoinduction [10, 64]. However, toxic factors should be observed. Ethylene 
oxide may be maintained in the graft and may interact or be released when in contact with any liquid, including blood. Gamma radiation may be toxic when in direct contact with fat that is present in the grafts $[27,37]$. Autoclaving is another way to sterilise grafts. However, xenografts must be sterilised at a temperature of $132^{\circ} \mathrm{C}$ to inactivate infectious proteins, i.e., prions, though this method reduces the mechanical resistance of xenografts in approximately $70 \%$ [62].

Frozen grafts from tissue banks undergo several protocols for donor selection before being used for transplantation. Graft rejects are reported to reach 20 to 30\% [4, 51]. But even with these severe protocols for selection, transmission of an infectious disease may occur $[25,53$, 55, 59. Sugihara et al [53] in 1999 reported the presence of tumour cells in frozen femoral heads and suggested inclusion of histopathological examinations as part of the screening protocol for donor tissues $[41,53]$.

The lyophilisation process until now has not been linked with infection as confirmed by Shibuya et al. [48], Ledford et al. [29] and Ribeiro et al. [44] who also reported no clinical signs of infections in patients submitted to revision of total hip arthroplasty with acetabular reconstruction, as well as no case of bovine spongiform encephalopathy disease (BSE) and its new variant the Creutzfeldt-Jakob disease (CJD). It is believed that lyophilisation process chemically inactivates most of the bacterial agents, viral and prion agents to a safe and acceptable level to be used in humans as reported by Wenz et al. [63] and among us, by Galia et al. [16] and Rosito et al. [45].

\section{Processing}

Several bone grafts storage ways are used all over the world. The two most widely accepted and used are the deep-frozen $\left(-80^{\circ} \mathrm{C}\right)$ and lyophilisation ones.

Extremely low temperatures $\left(<-80^{\circ} \mathrm{C}\right)$ are achieved by using temperature-controlled freezers equipped with power generators, just in case of lack of electric power cut, and alarms triggered by the system when the temperature increases. In these special freezers, a bone tissue can be maintained for up to 5 years. It should be noted that very low temperatures do not have a role in the sterilization of bone tissue.

Proposed and diffused by the Tissue Bank of USA Navy in 1951, the lyophilisation process became the technique in which bone is washed, centrifuged, decellularised, chemically degreased and subjected to physical processes of cleaning and sterilisation, and this way, only the protein-mineral matrix still remains in the graft, which is later frozen and then dehydrated. All these processes decrease antigenicity, tumour cell transmissions and inactivate prions [28, 35]. The lyophilisation is an important method of processing and storage for musculoskeletal tissues that allows not only the use of human bones, tendons and fascia (allogeneic) but also and mainly the bovine (xenogenic) [27, 31, 33, 39]. Currently, in major health centres, different types of bone grafts are available for reconstructive orthopaedic surgery: frozen and lyophilised autologous, (allogeneic) and lyophilised bovine grafts (xenogeneic) [2].

The frozen human graft (allogeneic) was the most used and widely accepted but the number of Tissue Banks in our country and in other developing countries is not enough to overcome the huge demand as well as the number of donors [47]. In the same way, as mentioned, there is a 
risk of transmission of diseases and tumour cells $[32,34,41,53]$. The vast majority of USA Tissue Banks produce lyophilised human grafts (allogeneic); however, there are few studies on its use or production. Therefore, lyophilised human grafts are still not widespread used among us $[8,56]$.

The bovine bone has a chemical composition, porosity, size, shape and biological behaviour similar to its human counterpart, although controversial bovine grafts is commonly used in dentistry surgeries and reconstructions [14]. It provides structural support, osteoconduction and a high content of calcium and phosphorus; essential factors for the newly formed bone tissue [40]. For these reasons, its use is growing in orthopaedic surgeries as reported by Prof. Galia [14] and by his co-workers in his research group, Rosito et al. [45, 46], Henning et al. [23] and Diesel et al. [9].

The most important issue is whether the graft has been processed and stored according to the standards of Associations of Tissue Banks and by national and international health authorities.

\section{Tissue banks}

Musculoskeletal tissue banks such as in the USA, there is an institution - the American Association of Tissue Banks (AATB) - to regulate and supervise the functioning of all incountry tissue banks since 1976 [1]. In Brazil, however, is the Ministry of Health, under the regulation order No. 55 (Dec. 2015) [24] that provides the technical regulations for the functioning of musculoskeletal and skin tissue banks of human origin, determining guidance from the facility characteristics, screening of living donors or cadavers up to equipment and human resources [24]. These regulations, though quite strict, have greatly improved the quality of tissue processing and safe use. For accrual, the decision to accept or reject a donor is carried out by the chairman of the Bank of Musculoskeletal Tissues (BMST) after rigorous tests and following an established protocol [38]. As the protocols used by the Tissue Banks, one must consider the history, physical examination and laboratory tests of the donor (Table 1).

\begin{tabular}{|c|c|c|c|}
\hline \multicolumn{4}{|c|}{ Summary protocol for screening of musculoskeletal tissue donors (bone, tendon and osteochondral) } \\
\hline \multirow{2}{*}{$\begin{array}{l}\text { NAME: } \\
\text { DATE OF BIRTH: }\end{array}$} & \multicolumn{3}{|l|}{ REGISTRY: } \\
\hline & AGE: & SEX: & COLOUR: \\
\hline \multicolumn{2}{|c|}{$\begin{aligned} \text { TYPE OF DONOR: ( ) DECEASED - BRAIN DEATH (BD) } \\
\text { ( ) DEAD - CARDIORESPIRATORY ARREST (CRA) } \\
\text { ( ) LIVE }\end{aligned}$} & \multicolumn{2}{|c|}{ TIME OF BD OR CRA: } \\
\hline \multicolumn{2}{|l|}{ DATE AND TIME OF COLLECTION: } & \multicolumn{2}{|c|}{ COLLECTION LOCATION: } \\
\hline $\begin{array}{l}\text { DATE AND TIME OF } \\
\text { CLINICAL/SOCIAL SCREENING: }\end{array}$ & $\begin{array}{l}\text { NAME AND } \\
\text { OF FAMILI }\end{array}$ & $\begin{array}{l}\text { D RELATI } \\
\text { IAR SCRE }\end{array}$ & \\
\hline
\end{tabular}




\begin{tabular}{|c|c|c|}
\hline \multicolumn{3}{|l|}{$\begin{array}{l}\text { ANAMNESIS } \\
\text { (The Tissue Bank should carry out a risk assessment for the selection of tissue donors } \\
\text { in case one or more of the situations below are observed) }\end{array}$} \\
\hline BODY INSPECTION & YES & NO \\
\hline \multicolumn{3}{|l|}{ presence of physical signs that have been at risk of malignant or sexually transmitted diseases, such as: } \\
\hline \multicolumn{3}{|l|}{ skin or mucosal lesions, including genital and perigenital or anal and perianal lesions } \\
\hline \multicolumn{3}{|l|}{ scars or surgical incisions prior to removal of tissues } \\
\hline \multicolumn{3}{|l|}{ jaundice } \\
\hline \multicolumn{3}{|l|}{ hepatomegaly } \\
\hline \multicolumn{3}{|l|}{ diffuselymphadenopathy } \\
\hline \multicolumn{3}{|l|}{ uncontrolled local infection at the time of donation, including bacterial, viral, fungal or parasitic infections } \\
\hline \multicolumn{3}{|l|}{$\begin{array}{l}\text { presence of piercing, tattooing or permanent makeup without evaluation conditions regarding the safety of } \\
\text { the procedure performed, done in the last } 12 \text { (twelve) months; if the procedures have been performed in } \\
\text { establishments regularized by health surveillance, the period to be considered is } 6 \text { (six) months, except for } \\
\text { the case of piercing in the oral and genital region, in which the period to be considered is } 12 \text { twelve } \\
\text { months }\end{array}$} \\
\hline \multicolumn{3}{|l|}{ use of injectable drugs or needle punctures suggestive of drug use in the donor's body; } \\
\hline CLINICAL / SOCIAL HISTORY & YES & No \\
\hline \multicolumn{3}{|l|}{$\begin{array}{l}\text { history of chronic, systemic and autoimmune disease capable of impairing the quality of tissues to be } \\
\text { donated }\end{array}$} \\
\hline \multicolumn{3}{|l|}{ history of travel and exposure to infectious agents, as well as the prevalence of local infectious diseases } \\
\hline \multicolumn{3}{|l|}{$\begin{array}{l}\text { use or exposure to toxic substances in the last } 12 \text { (twelve) months, such as cyanide, lead, mercury and } \\
\text { gold, which may be transmitted to the receptors at doses likely to endanger their health }\end{array}$} \\
\hline \multicolumn{3}{|l|}{ vaccine history, as provided in Ordinance No. 2,712 , of November 12,2013 or to replace it } \\
\hline \multicolumn{3}{|l|}{ laboratory tests anti-cytomegalovirus (CMV) (IgG) and anti-Toxoplasma (IgG) reagents } \\
\hline \multicolumn{3}{|l|}{$\begin{array}{l}\text { history, clinical data or presence of risk factors for transmission of Chagas' disease, syphilis, Zika or } \\
\text { Yellow Fever }\end{array}$} \\
\hline \multicolumn{3}{|l|}{$\begin{array}{l}\text { history, clinical data or presence of risk factors for transmission of human immunodeficiency virus (HIV-1 } \\
\text { and }-2 \text { ), hepatitis B virus (HBV), hepatitis C virus (HCV), and human T-lymphotropic virus (HTLV I and } \\
\text { II) }\end{array}$} \\
\hline EXCLUSION CRITERIA FOR TISSUE DONATION: & YES & NO \\
\hline \multicolumn{3}{|l|}{ unknown or undetermined cause of death } \\
\hline \multicolumn{3}{|l|}{ disease or history of disease of unknown aetiology } \\
\hline \multicolumn{3}{|l|}{$\begin{array}{l}\text { existence or history of malignant disease except for primary basal cell carcinoma, cervical carcinoma in } \\
\text { situ, and some primary tumours of the central nervous system }\end{array}$} \\
\hline \multicolumn{3}{|l|}{ transplanted organs } \\
\hline \multicolumn{3}{|l|}{$\begin{array}{l}\text { therapeutic use of tissues within a period of less than } 12 \text { (twelve) months, except in the predicted situation } \\
\text { in "diseases caused by prions", whose condition is definite exclusion for the donation }\end{array}$} \\
\hline \multicolumn{3}{|l|}{$\begin{array}{l}\text { uncontrolled systemic infection at the time of donation, including bacterial, viral, fungal or parasitic } \\
\text { infections, or significant local infection in donor tissues }\end{array}$} \\
\hline \multicolumn{3}{|l|}{$\begin{array}{l}\text { (HIV antibody + p24 antigen from HIV, including screening for antibodies against subtype 1, group O, } \\
\text { and subtype 2), HIV NAT, HBsAg, anti-HBcIgG or IgG + IgM, antibody + HCV antigen, HCV NAT, } \\
\text { antibody against HTLV I and II, anti-Trypanosoma cruzi antibody, anti-treponemic or non-treponemic } \\
\text { antibody. }\end{array}$} \\
\hline \multicolumn{3}{|l|}{$\begin{array}{l}\text { laboratory results of anti-CMV (IgG) and anti-Toxoplasma (IgG) reagents. } \\
\text { (the donation may be accepted but the transplant surgeon who will decide on the use of the donated tissue } \\
\text { must be informed) }\end{array}$} \\
\hline \multicolumn{3}{|l|}{ people who have undergone xenotransplantation } \\
\hline \multicolumn{3}{|l|}{ risk of transmission of diseases caused by prions; this risk applies, for example, to: } \\
\hline \multicolumn{3}{|l|}{$\begin{array}{l}\text { donors diagnosed with Creutzfeldt-Jakob disease, or with the variant of this disease or with a family } \\
\text { history of non-iatrogenic Creutzfeldt-Jakob disease }\end{array}$} \\
\hline \multicolumn{3}{|l|}{ history of rapidly progressive dementia or neurodegenerative diseases, including those of unknown origin } \\
\hline $\begin{array}{l}\text { donors treated with human growth hormone or other hormones of non-recombinant pituitary origin and } \\
\text { recipients of corneal, sclera and Dura mater transplantation, as well as persons who have undergone } \\
\text { undocumented neurosurgical intervention (in which it may have been used Dura mater) }\end{array}$ & & \\
\hline
\end{tabular}




\begin{tabular}{|c|c|c|}
\hline $\begin{array}{l}\text { the occurrence of haemodilution greater than } 50 \% \text { where a pre-transfusion and/or infusion sample is not } \\
\text { available or where there are no validated laboratory tests to be used in this type of sample }\end{array}$ & & \\
\hline treatment with immunosuppressive agents & & \\
\hline risk sexual practice in the past twelve (12) months, including: & & \\
\hline individuals who have had sex in exchange for money or drugs or their respective sexual partners & & \\
\hline individuals who have been victims of sexual violence or their respective sexual partners & & \\
\hline male individuals who have had sex with other same-sex individuals or their sexual partners & & \\
\hline $\begin{array}{l}\text { individuals who have had sexual intercourse with a person with HIV infection, HBV, HCV or other } \\
\text { sexually transmitted infection and blood or sex partners }\end{array}$ & & \\
\hline $\begin{array}{l}\text { individuals who are sexual partners of patients in a renal replacement therapy program and of patients with } \\
\text { a history of transfusion of blood components or blood products }\end{array}$ & & \\
\hline $\begin{array}{l}\text { individuals who have a history of incarceration or compulsory non-domicile confinement of more than } \\
\text { seventy-two ( } 72) \text { hours, or their sexual partners }\end{array}$ & & \\
\hline WEATHER TIME AND TEMPERATURE CONDITIONS & YES & No \\
\hline $\begin{array}{l}\text { Time between cardiorespiratory arrest (CRA) and tissue withdrawal of up to } 15 \mathrm{~h} \text { after PCR, if the donor } \\
\text { body is not kept under refrigeration; Or up to } 24 \text { hours after PCR if the donor's body is refrigerated within } \\
12 \text { hours after PCR. }\end{array}$ & & \\
\hline
\end{tabular}

\begin{tabular}{|c|c|c|c|}
\hline \multicolumn{4}{|c|}{ LABORATORY EXAMS } \\
\hline Exam & Result & Exam & Result \\
\hline haematocrithaemoglobin & & Leukocytes & \\
\hline erythrocyte sedimentation rate (ESR) & & Blood glucose & \\
\hline Bilirubins & & Alkaline phosphatase & \\
\hline Aspartate transaminase & & Alanine transaminase & \\
\hline Clog tests & & Platelets & \\
\hline Urine analysis & & Urine culture test & \\
\hline Detection of HBV surface antigen ( $\mathrm{HBsAg})$ & & $\begin{array}{l}\text { Antibody detection against HBV capsid } \\
\text { (anti-HBcIgG or } \operatorname{IgG}+\lg M \text { ) }\end{array}$ & \\
\hline $\begin{array}{l}\text { Detection of antibody against } \mathrm{HCV} \text { or } \\
\text { combined detection of antibody }+\mathrm{HCV} \\
\text { antigen }\end{array}$ & & $\begin{array}{l}\text { Detection of antibody against HIV or } \\
\text { combined detection of antibody against } \\
\text { HIV + HIV p } 24 \text { antigen. This test should } \\
\text { also include screening for antibodies } \\
\text { against subtype } 1 \text {, including group O, } \\
\text { and subtype 2; }\end{array}$ & \\
\hline $\begin{array}{l}\text { Detection of the antibody against HTLV I } \\
\text { and II }\end{array}$ & & $\begin{array}{l}\text { Detection of anti-Toxoplasma antibody } \\
\text { (lgG and } \mathrm{IgM})\end{array}$ & \\
\hline $\begin{array}{l}\text { Detection of the anti-Trypanosoma cruzi } \\
\text { antibody }\end{array}$ & & Epstein-Barr & \\
\hline $\begin{array}{l}\text { Detection of anti-CMV antibody (IgG and } \\
\text { IgM) }\end{array}$ & & $\begin{array}{l}\text { Antibody detection against HBV capsid } \\
\text { (anti-HBcIgG or } \operatorname{IgG}+\operatorname{IgM})\end{array}$ & \\
\hline NAT of HCV & & $\begin{array}{l}\text { Detection of anti-treponemic or non- } \\
\text { treponemic antibody to syphilis }\end{array}$ & \\
\hline HIV nucleic acid (NAT) detection test & & & \\
\hline \multicolumn{4}{|c|}{ RADIOGRAPHIC EXAMINATION } \\
\hline \multicolumn{4}{|c|}{$\begin{array}{l}\text { (Osteoarticular segments and long bones, kept as such for future transplantation, should undergo radiological examinations } \\
\text { for measurement and diagnosis of structural abnormalities) } \\
\text { Result: }\end{array}$} \\
\hline
\end{tabular}

Source: Musculoskeletal Tissue Bank (BTME) of São Vicente de Paulo Hospital - Passo Fundo. Tissue Bank Unit of the Hospital de Clínicas of Porto Alegre (UBMT-HCPA).

Table 1. Screening protocol for musculoskeletal tissue donors. 


\section{Conclusion}

There are many differences when comparing distinct types of graft. Thus, it is essential the implementation of protocols for processing and quality control of all types of bone grafts. This measure will facilitate the monitoring and analysis of the results and shall provide grafting material of better quality, thoroughly tested and readily available.

There is no doubt on the importance of bone transplants in orthopaedic surgery, especially in hip procedures. Their results are well known and, to some extent, predictable when used by experienced surgeons. It is undeniable, however, that we still know little about several issues regarding host-graft interaction. Therefore, further studies have yet to be carried out to attempt to address concerns on this matter that sometimes are overlooked or underestimated in order to achieve best clinical responses, increased biosafety and lower complication rates, i.e., better surgical outcomes [20, 22].

\section{Author details}

Carlos Roberto Galia ${ }^{1 *}$, Fernando Pagnussato ${ }^{2}$, Tiango Aguiar Ribeiro ${ }^{3}$ and Luis Fernando Moreira ${ }^{4}$

*Address all correspondence to: cgalia@hcpa.edu.br

1 Department of Surgery, Division of Orthopaedics Surgery, School of Medicine, Hospital de Clínicas de Porto Alegre, Rio Grande do Sul Federal University (UFRGS), Porto Alegre, RS, Brazil

2 School of Medicine, Hospital de Clínicas de Porto Alegre, Rio Grande do Sul Federal University (UFRGS), Porto Alegre, RS, Brazil

3 Department of Surgery, Division of Orthopaedics Surgery, School of Medicine, Santa Maria Federal University (UFSM), Santa Maria, RS, Brazil

4 Department of Surgery, Division of Surgical Oncology, School of Medicine, Rio Grande do Sul Federal University (UFRGS), Porto Alegre, RS, Brazil

\section{References}

[1] American Association of Tissue Banks-AATB's. http://www.aatb.org [Accessed: March 29th, 2011]

[2] Autograft, Allograft, and Xenograft [Lecture 17]. http://www.pharmacy.wisc.edu/courses/ 718-430/handouts/tisgraft.pdf [Accessed: February 27th, 2011]

[3] Barth H. Histologische Untersuchungen über Knochen-Transplantation. Beitrage zur pathologischen Anatomie und zur allgemeinen Pathologie. 1895;17:65-142 (in German) 
[4] Buck BE, Malinin TI. Human bone and tissue allografts. Preparation and safety. Clinical Orthopaedics and Related Research. SECTION 1 SYMPOSIUM: Bone and Tissue Allografts in the Reconstruction of the Knee: PDF Only. Jun 1994;303:8-17. Available in: <https://journals.lww.com/clinorthop/Abstract/1994/06000/Human_Bone_ and_Tissue_Allografts_Preparation_and.3.aspx>

[5] Buma P, Lamerigts N, Schreurs BW, Gardeniers J, Versleyen D, Slooff TJ. Impacted graft incorporation after cemented acetabular revision. Histological evaluation in 8 patients. Acta Orthopaedica Scandinavica. Dec 1996;67(6):536-540

[6] Cornu O, Bavadekar A, Godts B, Delloye C, Vantomme J, Banse X. Processed freezedried bone is more efficient than fresh frozen for impaction bone grafting. In: 47th Annual Meeting, Orthopaedic Research Society; Feb 25-28; San Francisco, California; 2001. pp. 1081-1081

[7] Czitrom AA, Axelrod T, Fernandes B. Antigen presenting cells and bone allotransplantation. Clinical Orthopaedics and Related Research. Jul-Aug 1985;(197):27-31

[8] deRoeck NJ, Drabu KJ. Impaction bone grafting using freeze-dried allograft in revision hip arthroplasty. The Journal of Arthroplasty. Feb 2001;16(2):201-206

[9] Diesel CV, Ribeiro TA, Guimarães MR, Macedo CAS, Galia CR. Acetabular revision in total hip arthroplasty with tantalum augmentation and lyophilized bovine xenograft. Revista Brasileira de Ortopedia. Aug 2017;52(Suppl 1):46-51

[10] Fideler BM, Vangsness CT Jr, Lu B, Orlando C, Moore T. Gamma irradiation: Effects on biomechanical properties of human bone-patellar tendon-bone allografts. American Journal of Sports Medicine. Sep-Oct 1995;23(5):643-646

[11] Finkemeier CG. Bone-grafting and bone-graft substitutes. Journal of Bone and Joint Surgery. Mar 2002;84A(3):454-464

[12] Fred A II. The fundamental principles involved in the use of the bone graft in surgery. The American Journal of the Medical Sciences. Mar 1915;149(3):313-325

[13] Friedlaender GE, Strong DM, Sell KW. Studies on the antigenicity of bone. I. Freezedried and deep-frozen bone allografts in rabbits. Journal of Bone and Joint Surgery. Sep 1976;58(6):854-858

[14] Galia CR. Lyophilised impacted bone grafts from human and bovine origin in TRHAs. Porto Alegre, 2004, 127p. Doctorate Thesis - Faculty of Medicine, Post-graduate Programme in Surgery. Rio Grande do Sul Federal University; 2004

[15] Galia CR, Lourenço AL, Rosito R, Macedo CAS, Camargo LMAQ. Physicochemical characterization of lyophilized bovine bone grafts. Revista Brasileira de Ortopedia. Apr 2011;46(4):444-451

[16] Galia CR, Macedo CA, Rosito R, Mello TM, Camargo LM, Moreira LF. In vitro and in vivo evaluation of lyophilized bovine bone biocompatibility. Clinics. Dec 2008;63(6):801-806

[17] Garcia VD. Tissue and Organ Transplants. 2nd ed. São Paulo, SP, Brazil; 2006 
[18] Gie GA, Linder L, Ling RS, Simon JP, Slooff TJ, Timperley AJ. Impacted cancellous allografts and cement for revision total hip arthroplasty. The Journal of Bone and Joint Surgery. Jan 1993;75(1):14-21

[19] Godwin L. Tissue Banking and Allograft Transplantation. Jun 2000. http://www.iscpubs. com/articles/abl/b0006god.pdf [Accessed: November 22nd, 2003]

[20] Goldberg VM. Selection of bone grafts for revision total hip arthroplasty. ClinOrthop. Dec 2000;381:68-76

[21] Gonçalves HR. Methods of acetabular bone graft incorporation in THA with bone loss [dissertation]. São Paulo, SP, Brazil: Santa Casa de São Paulo Faculty of Medical Sciences; 2003. (In Portuguese)

[22] Heliotis M, Tsiridis EE. Fresh frozen bone in femoral impaction grafting: Can developments in bone regeneration improve on this? Medical Hypotheses. Dec 2001;57(6): 675-678

[23] Henning C, Poglia G, Leie MA, Galia CR. Comparative study of subtalar arthrodesis after calcaneal fracture malunion with autologous bone graft or freeze-dried xenograft. Journal of Experimental Orthopaedics. Dec 2015;2(1):10

[24] ImprensaNacional. A fonteoficial da informação. DiárioOficial no 238, Seção 1, 14 dedezembro de 2015. AgênciaNacional de VigilânciaSanitária. DiretoriaColegiada. Resolução-RDC n 55, de 11 de dezembro de 2015. Disponívelem: http://pesquisa.in.gov. br/imprensa/jsp/visualiza/index.jsp?data=14/12/2015\&jornal=1\&pagina=55\&totalArqui vos=152. [Accessed: March 12th, 2018]

[25] Invasive Streptococcus pyogenes after Allograft Implantation-Colorado; 2003. http://www. cdc.gov/mmwr/preview/mmwrhtml/mm5248a1.htm [Accessed: January 23rd, 2011]

[26] Itoman M, Nakamura S. Experimental study on allogenic bone grafts. International Orthopaedics. 1991;15(2):1615

[27] Kakiuchi M, Ono K, Nishimura A, Shiokawa H. Preparation of bank bone using defatting, freeze-drying and sterilisation with ethylene oxide gas. Part 1. Experimental evaluation of its efficacy and safety. International Orthopaedics. 1996;20(3):142-146

[28] Kreuz FP, Hyatt GW, Turner TC, et al. The preservation and clinical use of freeze-dried bone. Journal of Bone and Joint Surgery (American). 1951;33:863-873

[29] Ledford CK, Nunley JA II, Viens NA, Lark RK. Bovine xenograft failures in pediatric foot reconstructive surgery. Journal of Pediatric Orthopaedics B. Jun 2013;33(4): $458-463$

[30] Lexer E. Joint transplantations and arthoplasty. Surgery, Gynecology \& Obstetrics. 1925;40:782-809

[31] Li Z-z, Shi-bi L, Ji-fang W. The study of repairing ability of freeze-dried bone allograft. ZhonghuaWaiKeZaZhi. Dec 1994;32(12):765-767. (English abstract) 
[32] Lind M, Krarup N, Mikkelsen S, Horlyck E. Exchange impaction allografting for femoral revision hip arthroplasty: Results in 87 cases after 3.6 years follow-up. The Journal of Arthroplasty. Feb 2002;17(2):158-164

[33] Liu W. Reconstitution of osteoinductive bone xenograft: bioassay in mice. Zhonghua Yi XueZaZhi. 28 Jul 1991;71(7):378-380. (English abstract)

[34] Lubboc. Maitriseorthopédique. http://www.maitrise-orthop.com/ gesto/lubboc.shtml (in French). [Accessed: February 10th, 2018]

[35] Lucchese AC, Dec hechi ED. Lyophilisation process. In: XI Research and Bioethics Meeting 2003 (Oct 20th-22nd); Porto Alegre, RS, Brazil. www2.pucpr.br/educacao/ pibic//evento/files/CE08.html. [Accessed: May 4th, 2018]

[36] Macedo CAS, Galia CR, Silva ALB, César PC, Sanches PRS, Duarte LS, et al. Compression resistance of deep-frozen and freeze-dried bone of bovine origin. Revista Brasileira de Ortopedia. 1999;34(9/10):529-533 (in Portuguese)

[37] Moreau MF, Gallois Y, Basle MF, Chappard D. Gamma irradiation of human bone allografts alters medullary lipids and releases toxic compounds for osteoblast-like cells. Biomaterials. Feb 2000;21(4):369-376

[38] National Presse. Brazil's official Press $n^{\circ} 185$, 1, Section Sept 24th, 2002. Norm $n^{\circ}$ 1.686, Sept 20th, 2002. https://www.in.gov.br/imprimir.asp?id=1081142100\&tela=imp. [Accessed: April 22th, 2018]

[39] Nogami H, Urist MR. Explants, transplants and implants of a cartilage and bone morphogenetic matrix. Clinical Orthopaedics and Related Research ${ }^{\circledR}$. Basic Science And Pathology: PDF Only. 1974;103:235-251. Available in: <https://journals.lww.com/clinorthop/Citation/1974/09000/Explants,_Transplants_and_Implants_of_a_Cartilage.85. aspx>

[40] Oliveira RC, Sicca CM, Silva TL, Cestari TM, Oliveira OT, Buzalaf MAR, et al. Temperature effect on the denaturation of microgranular cortical bone of bovine origin. Microscopic and biochemistry assessment of cell response in rats. Revista FOB. Jul/Dez 1999;7(3/4):85-93 (in Portuguese)

[41] Palmer SH, Gibbons CL, Athanasou NA. The pathology of bone allograft [abstract]. The Journal of Bone and Joint Surgery. British Volume. Mar 1999;81(2):333-335

[42] Poumarat G, Squire P. Comparison of mechanical properties of human, bovine bone and a new processed bone xenograft. Biomaterials. Apr 1993;14(5):337-340

[43] Reddi AH, Cunningham NS. Initiation and promotion of bone differentiation by bone morphogenetic proteins [abstract]. Journal of Bone and Mineral Research. Dec 1993;8(Suppl 2):S499-S502

[44] Ribeiro TA, Coussirat C, Pagnussato F, Diesel CV, Macedo FCS, Macedo CAS, Galia CR. Lyophilized xenograft: a case series of histological analysis of biopsies. Cell Tissue Bank. Jun 2015;16(2):227-233 
[45] Rosito R, Galia CR, Macedo CA, Moreira LF, Quaresma LM, Palma HM. Acetabular reconstruction with human and bovine freeze-dried bone grafts and a reinforcement device. Clinics. 2008;63(4):509-514

[46] Rosito R, Galia CR, Macedo CA, Quaresma LM, Moreira LF. Mid-term follow-up of acetabular reconstruction using bovine freeze-dried bone graft and reinforcement device. Revista Do Colegio Brasileiro De Cirurgioes. Jul 2009;36(3):230-235

[47] Seiler 3rd JG, Johnson J, Hand G, Microsurgery Clinic. Iliac crest autogenous bone grafting: Donor site complications. Journal of the Southern Orthopaedic Association [Online]. Internet: http://www.medscape.com/viewarticle/410431 [Accessed: September 7th, 2011]

[48] Shibuya N, Jupiter DC, Clawson LD, La Fontaine J. Incorporation of bovine-based structural bone grafts used in reconstructive foot surgery. The Journal of Foot \& Ankle Surgery. Jan-Feb 2012;51(1):30-33

[49] Slooff TJ, Buma P, Schreurs BW, Schimmel JW, Huiskes R, Gardeniers J. Acetabular and femoral reconstruction with impacted graft and cement. Clinical Orthopaedics and Related Research. Mar 1996;(324):108-115

[50] Slooff TJ, Huiskes R, van Horn J, Lemmens AJ. Bone grafting in total hip replacement for acetabular protrusion [abstract]. Acta Orthopaedica Scandinavica. Dec 1984;55(6):593-596

[51] Sommerville SM, Johnson N, Bryce SL, Journeaux SF, Morgan DA. Contamination of banked femoral head allograft: incidence, bacteriology and donor follow up [abstract]. The Australian and New Zealand Journal of Surgery. Jul 2000;70(7):480-484

[52] Springfield DS. Massive autogenous bone grafts. Orthopedic Clinics of North America. Apr 1987;18(2):249-256

[53] Sugihara S, van Ginkel AD, Jiya TU, van Royen BJ, van Diest PJ, Wuisman PI. Histopathology of retrieved allografts of the femoral head. The Journal of Bone and Joint Surgery. British Volume. Mar 1999;81(2):336-341

[54] Tägil M. The Morselized and Impacted Bone Graft. Animal Experiments on Proteins, Impaction and Load [Thesis]. Lund (Sweden): Lund University Hospital; 2000

[55] Taylor D. Inactivation of the BSE agent. Comptes Rendus de l'Académie des Sciences Series III. Jan 2002;325(1):75-76

[56] Thien TM, Welten ML, Verdonschot N, Buma P, Yong P, Schreurs BW. Acetabular revision with impacted freeze-dried cancellous bone chips and a cemented cup: a report of 7 cases at 5 to 9 years follow-up. The Journal of Arthroplasty. Aug 2001;16(5):666-670

[57] Turek SL. Orthopaedics: Principles and Applications. 4th ed. EditoraManoleLtda, Rio de Janeiro, RJ, Brazil. p.756; 1991 (in Portuguese)

[58] Ullmark G, Obrant KJ. Histology of impacted bone-graft incorporation. The Journal of Arthroplasty. Feb 2002;17(2):150-157 
[59] Update: Allograft-associated Bacterial Infections-United States, 2002. 4th Nov, 2002. http://www.medscape.com/viewarticle/430131 [Accessed: June 9th, 2011]

[60] Urist MR, Hernandez A. Excitation transfer in bone. Deleterious effects of cobalt 60 radiation-sterilization of bank bone. Archives of Surgery. Oct 1974;109(4):486-493

[61] Vajaradul Y. Bone banking in Thailand. A 10-year experience (1984-1994). Clinical Orthopaedics and Related Research. Feb 1996;323:173-180

[62] Viceconti M, Toni A, Brizio L, Rubbini L, Borrelli A. The effect of autoclaving on the mechanical properties of bank bovine bone [abstract]. La Chirurgia degli Organi di Movimento. Jan-Mar 1996;81(1):63-68

[63] Wenz B, Oesch B, Horst M. Analysis of the risk of transmitting bovine spongiform encephalopathy through bone grafts derived from bovine bone. Biomaterials. Jun 2001; 22(12):1599-1606

[64] Zhang Q, Cornu O, Delloye C. Ethylene oxide does not extinguish the osteoinductive capacity of demineralized bone. A reappraisal in rats. Acta Orthopaedica Scandinavica. Apr 1997;68(2):104-108 
